\title{
Nesting in the lizard Phyllopezus pollicaris (Squamata: Phyllodactylidae) and a phylogenetic perspective on communal nesting in the family
}

\author{
Fabricius M. C. B. Domingos, ${ }^{1,2}$ Ísis C. Arantes, ${ }^{3}$ Renan J. Bosque, ${ }^{3}$ and Marcella G. Santos ${ }^{3}$ \\ ${ }^{1}$ Programa de Pós-Graduação em Ecologia e Conservação, Universidade do Estado de Mato Grosso, $78690-000$ Nova \\ Xavantina, MT, Brazil. E-mail: fabriciusmaia@gmail.com. \\ ${ }^{2}$ Instituto de Ciências Biológicas e da Saúde, Universidade Federal de Mato Grosso, 78698-000 Pontal do Araguaia, MT, Brazil. \\ ${ }^{3}$ Department of Biology, University of Mississippi, Oxford, Mississippi 38677, USA.
}

\begin{abstract}
Nesting in the lizard Phyllopezus pollicaris (Squamata: Phyllodactylidae) and a phylogenetic perspective on communal nesting in the family. Communal nesting occurs in many reptile species. The hypotheses that explain the evolution of such behaviours are still controversial, but will be better understood as more communal nesting records are described in the literature. We report the findings of two communal nests of Phyllopezus pollicaris, including the largest known nest for the species. Our study is the first to provide a communal nesting record for squamate species in a Cerrado core area. We provide nest photographs and detailed neonate measurements and weight. Nests were found during the dry season, in contrast with the reproduction pattern previously described for the species in the Cerrado periphery. We also conducted an extensive literature review seeking all available information on communal nesting information in Phyllodactylidae, and present this information in the context of a phylogenetic tree of phyllodactylid genera. We suggest that studying the correlation between communal nesting evolution and reproductive investment will become a fertile field as more information on lizard nesting becomes available in the literature.
\end{abstract}

Keywords: Brazil, Cerrado, lizards, nest, phylogeny, reproduction.

\begin{abstract}
Resumo
Ninhadas de Phyllopezus pollicaris (Squamata: Phyllodactylidae) e uma perspectiva filogenética de ninhadas comunais para a família. Ninhadas comunais são encontradas em várias espécies de répteis. As hipóteses que explicam a evolução desse comportamento ainda são controversas, mas serão melhor compreendidas à medida que mais registros de ninhadas comunais forem descritos na literatura. Neste estudo, registramos duas ninhadas comunais de Phyllopezus pollicaris, incluindo a maior ninhada conhecida para a espécie. Este é o primeiro estudo a registrar ninhadas comunais para
\end{abstract}

Received 19 January 2017

Accepted 27 July 2017

Distributed December 2017 
uma espécie de Squamata em uma região central do Cerrado. Além disso, também apresentamos fotografias das ninhadas, assim como medidas detalhadas e peso dos neonatos. As ninhadas foram encontradas durante a estação seca, em contraste com o padrão reprodutivo previamente descrito para a espécie na periferia do Cerrado. Nós também realizamos uma extensa revisão bibliográfica a respeito de ninhadas comunais na família Phyllodactylidae e apresentamos os resultados no contexto de uma árvore filogenética dos gêneros da família. Finalmente, sugerimos que estudar a correlação entre a evolução de ninhadas comunais e o investimento reprodutivo se tornará um campo de estudo fértil à medida que mais informações sobre ninhadas comunais estiverem disponíveis na literatura científica.

Palavras-chave: Brasil, Cerrado, filogenia, lagartos, ninho, reprodução.

\section{Introduction}

Communal nesting, the phenomenon by which different females of one or more species deposit eggs at a shared nest (Noble and Mason 1933), occurs in many squamate species (Graves and Duvall 1995). The evolutionary and ecological processes resulting in this behavior are hypothesized to be related to either environmental constraints or selective advantage (Doody et al. 2009). Early attempts to explain squamate communal nesting suggested that this phenomenon was simply a factor of nesting site scarcity (Rand 1967, Vitt 1986). More recent studies, however, advocate that communal nesting evolved through natural selection, since there are potential energetic and reproductive advantages for females that use communal nests. These advantages could be related to less time spent searching and building nests (Graves and Duvall 1995), and to increased offspring performance and/or survivorship (Radder and Shine 2007). Research that used both field collected data and laboratory experiments support the latter hypothesis, and found that communal nesting provided a fitness increase for the involved females (Blouin-Demers et al. 2004, Radder and Shine 2007). Nonetheless, the relative prevalence of these alternative processes has not been investigated in a comparative macroevolutionary approach (Doody et al. 2009).

Communal nesting has evolved independently several times during the history of squamates
(Doody et al. 2009), but appears to be particularly prevalent in geckos (Graves and Duvall 1995, Doody et al. 2009). Clutch size is a phylogenetically conserved attribute in geckos (Vitt 1986, Sinervo 1994), and most species produce only one or two eggs at a time (Mesquita et al. $2015,2016 a$ ), which is a relatively small number compared to most other lizard families (Mesquita et al. 2016b). The repeated evolution of communal nesting in geckos might be a behavioral adaptation in response to this clutch size constraint, as it potentially increases female fitness through better hatchling performance (Blouin-Demers et al. 2004, Radder and Shine 2007).

A few Neotropical geckos are known to nest communally, such as Coleodactylus meridionalis (Boulenger, 1888) in the Caatinga (Oliveira et al. 2015), Hemidactylus agrius Vanzolini, 1978 in the Caatinga (Bezerra et al. 2011), Phyllopezus periosus Rodrigues, 1986 in the Caatinga (Lima et al. 2011), and Gonatodes humeralis (Guichenot, 1855) in the Amazon (Vitt et al. 1997, Oda 2004), among others. To the best of our knowledge, the only known gecko that produces communal nests in the Cerrado, the Brazilian savanna, is Phyllopezus pollicaris (Spix, 1825) (Righi et al. 2004). Despite the fact that the Cerrado is a biodiversity hotspot (Myers et al. 2000) and houses a high proportion of South American lizard diversity (Colli et al. 2002, Nogueira et al. 2011), natural history information on the reproductive ecology of 
Cerrado lizards are still scarce (e.g., Colli 1991, Wiederhecker et al. 2002, Colli et al. 2003).

The lizard Phyllopezus pollicaris is distributed across the dry-diagonal biomes of South America (Caatinga, Cerrado, and Chaco) (Werneck and Colli 2006). Although there are no recent taxonomic changes related to the status of $P$. pollicaris, it is certainly a species complex composed of many cryptic lineages (Gamble et al. 2012, Werneck et al. 2012). In terms of habitat use, $P$. pollicaris is mostly found on rock outcrops (Werneck et al. 2009), either granite (Vitt 1986) or sandstone (Recoder et al. 2012), where they forage and lay their eggs (Righi et al. 2004, Recoder et al. 2012). Individuals of this species are surface active during the night and usually found within rock crevices during the day (Recoder et al. 2012). According to literature records, $P$. pollicaris is only known to produce two eggs (Vitt 1986, Ávila and Cunha-Avellar 2005, Recoder et al. 2012, Righi et al. 2012).

Vitt (1986) was the first author to suggest that Phyllopezus pollicaris will nest communally, and found nests with a maximum number of six eggs (probably produced by three females) in the Caatinga biome. Ávila and Cunha-Avellar (2005) recorded a similar instance (single nest with six eggs) in seasonally-dry forests in western Brazil. Finally, Righi et al. (2004) found five communal nests with two to 10 eggs (i.e., produced by up to five females) in a Cerrado peripheral area, southeastern Brazil. The only available information on neonates of this species is average snout vent length and weight, which were based on a limited number of individuals (Vitt 1986), and snout vent length and tail length of two individuals (Gomides and Garcia 2014). Herein, we report the largest communal nest found for $P$. pollicaris, provide the first record of squamate communal nesting in a Cerrado core area, and visual records of such nests in the biome. We also provide detailed neonate measurements and weight (Table 1, Appendix I). Finally, we present this information with a communal nesting phylogenetic perspective for the family Phyllodactylidae.
Table 1. Descriptive statistics of body measurements $(\mathrm{mm})$ and mass $(\mathrm{g})$ of Phyllopezus pollicaris neonates $(N=22)$ from two communal nests in the Cerrado biome.

\begin{tabular}{lc}
\hline Neonates measurements & Mean \pm SD \\
\hline Mass & $0.88 \pm 0.06$ \\
Snout vent length & $32.53 \pm 1.12$ \\
Tail length & $34.19 \pm 1.53$ \\
Body width & $6.65 \pm 0.65$ \\
Body height & $4.57 \pm 0.48$ \\
Head width & $6.90 \pm 0.40$ \\
Head height & $3.82 \pm 0.30$ \\
Head length & $9.80 \pm 0.58$ \\
Anterior limb length & $9.91 \pm 0.70$ \\
Posterior limb length & $13.62 \pm 0.71$ \\
\hline
\end{tabular}

\section{Materials and Methods}

We searched for Phyllopezus pollicaris nests for three consecutive days (18-20 May 2013) at Parque Nacional Chapada dos Veadeiros (Alto Paraíso de Goiás, Goiás state, Brazil), a large protected area at the core of the Cerrado biome. Searches were conducted in a 'cerrado rupestre'

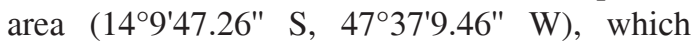
consists of typical cerrado (savanna) vegetation growing amidst sandstone rock outcrops (Figure 1A, B). Sandstone rocks are found in many different sizes, and it is common for lizards to hide and nest under rocks laying on top of larger rocks (Recoder et al. 2012). Hence, we spent $\sim 8$ hours per day searching for eggs in rock crevices, and also lifting smaller rocks, since nests could potentially be found under such rocks. When found, all eggs from a nest were collected, taken to the laboratory to hatch, and kept at room temperature $\left(\sim 21^{\circ} \mathrm{C}\right)$ in separate closed plastic containers (lids had holes to allow for gas exchange). Since there was no soft substrate in 
the rocks where eggs were collected (e.g., litter or sand), they were kept in exfoliated vermiculite.

Neonates were killed immediately after hatching using a $2 \%$ lidocaine hydrochloride injection. Body measurements of the neonates were taken to the nearest $0.01 \mathrm{~mm}$ using a digital caliper (Mitutoyo ${ }^{\circledR}$ ), and weighing to the nearest $0.01 \mathrm{~g}$ was performed using a digital scale (A\&D Company $\left.{ }^{\circledR}\right)$. To allow for future genetic investigations, we also extracted the liver from all lizards after measurements were performed. Livers were preserved in 99\% ethanol, and lizards were fixed in $10 \%$ formalin. All lizards and tissue samples were deposited at Coleção Herpetológica da Universidade de Brasília (CHUNB) (Appendix I).

To place our results in a broader evolutionary perspective within the Phyllodactylidae, we conducted a literature review of published information on communal nesting for this family. We sought published papers and notes on nests of all synonyms of the 135 currently described species of Phyllodactylidae (Uetz 2016). Since the absence of communal nesting behavior is virtually impossible to determine, it becomes impractical to reconstruct the evolution of this trait in a phylogenetic context using only the relatively few cases where communal nesting is actually present. Hence, following the approach of Doody et al. (2009), we plotted the available information in a phylogenetic tree of all currently recognized phyllodactylid genera, in order to visualize the macroevolutionary patterns of this behavior. We used the most recent Squamate phylogenetic estimate (Tonini et al. 2016), and pruned the tree so it would only depict the relationships among phyllodactylid genera, using the package ape (Paradis et al. 2004) in $\mathrm{R}$ version 3.3.1 (R Core Team 2016).

\section{Results}

We found two Phyllopezus pollicaris communal nests, one containing 25 eggs (Figure 1C, D), hereafter Nest 1, and another containing six eggs (Figure 1E), Nest 2. Both nests were found on 19 May 2013 under stacked rocks. All eggs were hard shelled and oviposition occurred directly on the rocks. From Nest 1, 80\% of the eggs hatched $(N=20)$, and from Nest $250 \%(N$ $=3)$. Incubation time since field collection ranged from 3 to 112 days (mean \pm SD: $30 \pm$ 32.5 days; Appendix I). Neonates measurement and mass descriptive statistics can be found in Table 1.

In our literature review, out of the 135 currently described phyllodactylid species, we found 21 species for which communal nesting evidence is available (Table 2), distributed among seven out of the 10 phyllodactylid genera (Figure 2, Appendix II).

\section{Discussion}

Females of Phyllopezus pollicaris may take up to three months to produce eggs when reproduction season starts (i.e., time between first vitellogenic follicles and first gravid females are found) (Righi et al. 2012), and it took between three and 112 days for our captured eggs to hatch in captivity. Hence, it is not possible, at this stage, to evaluate whether at least some ovipositions in $P$. pollicaris communal nests were produced by the same females. We believe that future genetic investigations using the collected tissue samples, and possibly other nests, might clarify this issue.

The uneven number of eggs in Nest 1 is somewhat surprising, because Phyllopezus pollicaris is believed to always produce two eggs (Vitt 1986, Righi et al. 2012). This finding might be explained by egg predation, or simply by the female's choice to lay one egg at a separate location, since no empty shells were found at Nest 1 . Although very unlikely, the fact that we found the same incubation time for three eggs in two distinct cases (Appendix I), and the arrangement of two rows of three eggs each in Nest 2 (Figure 1E) might suggest that $P$. pollicaris could produce up to three eggs in our study site. We visually inspected all Chapada dos Veadeiros $P$. pollicaris specimens deposited 


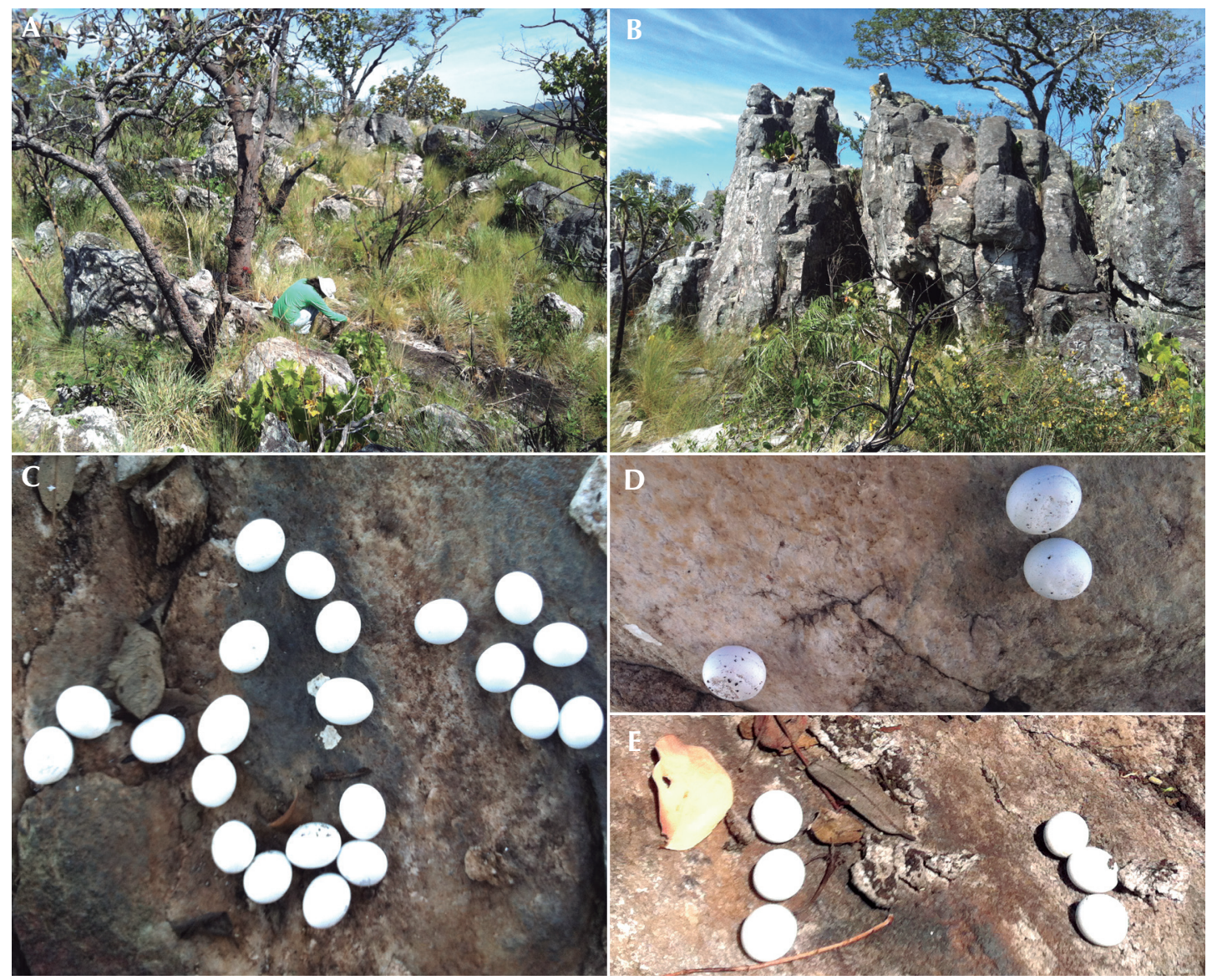

Figure 1. Phyllopezus pollicaris communal nests. (A-B) The 'cerrado rupestre' habitat at Parque Nacional da Chapada dos Veadeiros. Nest 1 with 25 eggs, (C) 22 at the bottom rock and (D) three stuck at the top rock. (E) Nest 2 with six eggs disposed in two rows of three eggs each. Photographs of nests were taken after the removal of the top rocks during the searches.

at CHUNB $(N=22)$ but, unfortunately, there were no pregnant females that could shed light on this question. This hypothesis might be tested when more $P$. pollicaris communal nests are found, and specimens are collected during the reproductive season at Chapada dos Veadeiros.

Vitt (1986) suggested that communal nesting by geckos in arid areas might simply be a factor of the limited amount of nesting sites. However, we spent $\sim 24$ working hours checking many possibly suitable nesting sites and found only two nests. Since nesting sites appear to be abundant in the area, and considering that one nest contained such a large number of eggs (25), we suggest that Vitt's assumption might not be true for $P$. pollicaris living in the Cerrado. The alternative explanation, that communal nesting might increase $P$. pollicaris female fitness because of egg insulation, predation abatement, increased hatchling quality, or other mechanisms, 


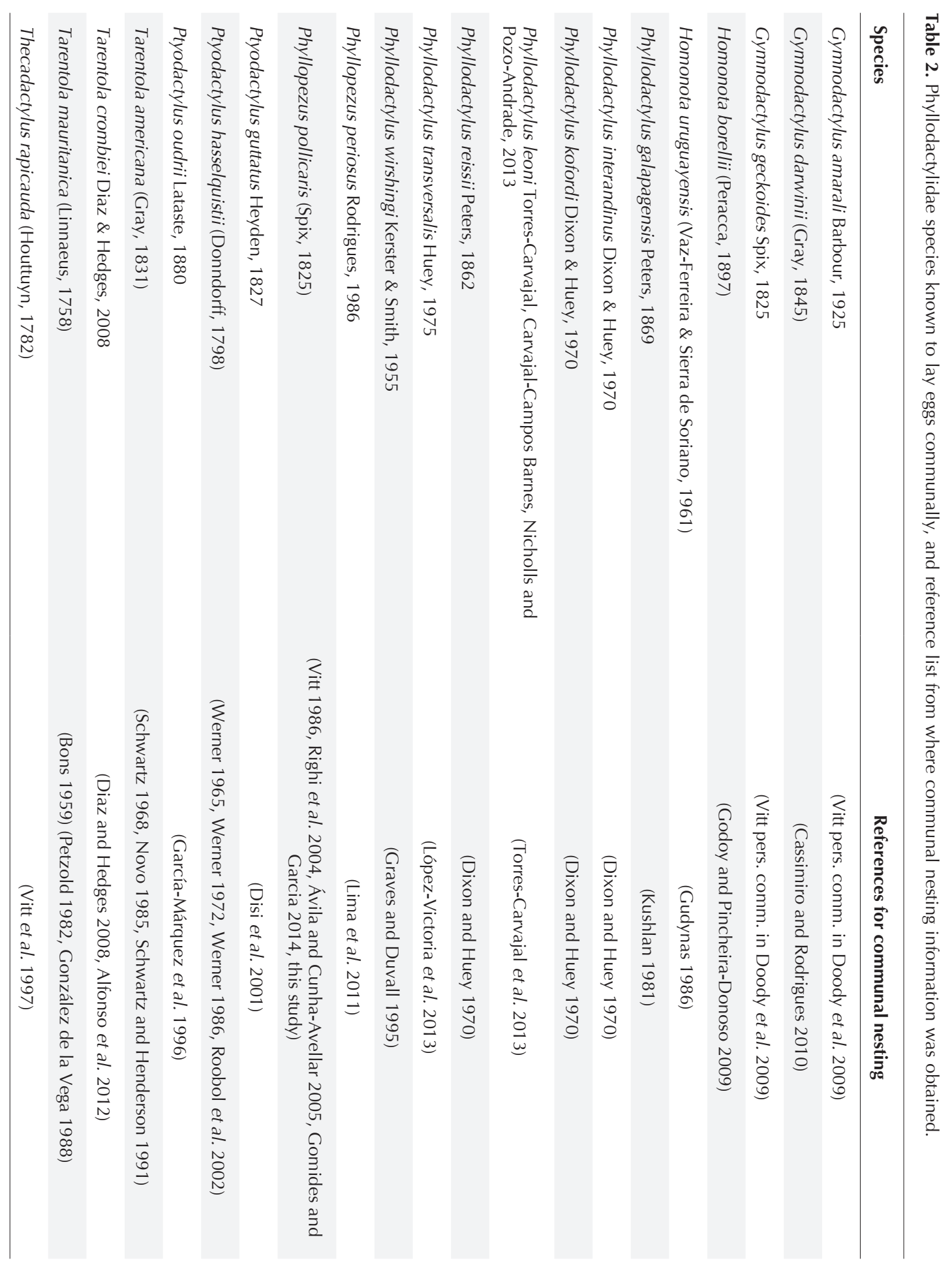




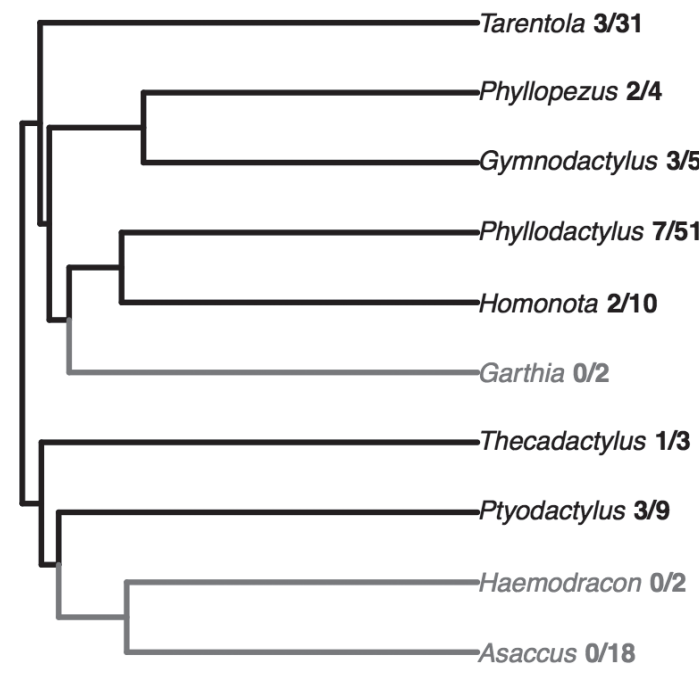

Figure 2. Phylogenetic relationships among currently recognized genera of Phyllodactylidae (number of species know to nest communally/ number of species in the genus). Tree adapted from Tonini et al. (2016). Genera known to lay eggs communally are in black, and genera for which no evidence of communal nesting is available are in gray.

should be further studied to test this suggestion (Doody et al. 2009).

Interestingly, Phyllopezus pollicaris reproduces throughout the year in the Caatinga (Vitt 1986), but only between August and December in the Cerrado (Righi et al. 2012), during the end of the dry season and through part of the wet season (Eiten 1972). The same pattern is true for two other phyllodactylid sister species: Gymnodactylus geckoides Spix, 1825, which reproduces continuously in the Caatinga, and G. amarali Barbour, 1925 which reproduces during the Cerrado dry season (Colli et al. 2003). This pattern is probably related to the unpredictability of Caatinga's climate, leading lizards to constantly invest in reproduction (Colli 1991, Mesquita et al. 2016a), and also suggests that large Phyllodactylidae communal nests will be mostly found in the Cerrado biome, where reproduction is concentrated in a few months. On the other hand, we found nests at the start of the dry season, outside the estimated reproduction time for $P$. pollicaris in another Cerrado location (Diamantina, Minas Gerais state) at the southeastern border of the biome (Righi et al. 2012). It is beyond the scope of this manuscript to infer reproduction seasonality aspects of $P$. pollicaris, but such large difference might be related to climatic differences between both localities, or to the cryptic lineages within the species (Werneck et al. 2012). Coincidently, reproduction of other phyllodactylid species, G. amarali, is also concentrated during the dry season in Cerrado core areas (Colli et al. 2003). The same is not true for other lizard species such as Ameiva ameiva (Linnaeus, 1758) (Colli 1991) and Tropidurus torquatus (Wied-Neuwied, 1820) (Wiederhecker et al. 2002) which reproduce during the wet season at the core of Cerrado. Hence, there is also the possibility that differences between the peripheral and core Cerrado climate influences this shift in the reproduction patterns of phyllodactylid species (Furley 1999, Souza et al. 2015).

Communal nests may provide thermal insulation for eggs, which could in turn lead to increased growth of embryos and a fitness advantage for females (Blouin-Demers et al. 2004). This is apparently true in temperate regions, but could be an important selective pressure in the cold nights of the Cerrado dry season. If this hypothesis is true, we predict that: (1) within populations, neonates from nests with fewer eggs would be smaller than neonates from nests with more eggs; and (2) between populations, we would find nests with more eggs in colder regions as opposed to nests with fewer eggs in warmer regions. We could not detect a significant difference in body sizes of neonates from the two nests sampled in this study (results not shown), contradicting our first prediction. On the other hand, we registered the largest $P$. pollicaris communal nest to date, as opposed to smaller nests found both in the Caatinga (Vitt 
1986, Gomides and Garcia 2014), which presents warmer climate, and in the Cerrado during the wet season (Righi et al. 2012), which is usually warmer than the dry season. Average snout vent length of $P$. pollicaris neonates in this study $(32.53 \pm 1.12 \mathrm{~mm})$ was similar to the measurements obtained by Vitt (1986) in a Caatinga area $(31.0 \pm 0.55 \mathrm{~mm})$. However, a sample of two laboratory hatched $P$. pollicaris also from the Caatinga were considerably smaller $(24.82 \pm 0.04 \mathrm{~mm})$ (Gomides and Garcia 2014). Investigating the possible fitness advantage of communal nesting on neonate size would require a comprehensive database of hatchlings size and adult females among populations of $P$. pollicaris (and closely related species), and our complete set of measurements will be a valuable source of information for future comparative studies. This hypothesis should also be explored in an integrative approach, by testing the effects of temperature on embryo development in the laboratory, and by assessing nests microclimate in the field.

Alternatively, communal nesting might have little or no effect on neonate size in Phyllodactylidae, since the rigid eggshell acts as an important constraint in this trait (Pike et al. 2011). In lineages with fixed clutch size, allocating resources for multiple clutches per reproductive season is a common strategy to increase reproductive success (Meiri et al. 2012, 2015). Genetic analysis of the samples collected in this study will provide a rare opportunity to detect if females are producing multiple clutches and using the same nesting site. Nevertheless, considering the constraints in the reproductive biology of phyllodactylids, communal nesting could represent a significant fitness advantage for $P$. pollicaris individuals. Some of the adaptive hypotheses that might explain this phenomenon in the species include reduction in eggs predation, reduction in energetic costs to find nesting sites for females, and increasing survival of embryos and hatchlings (Graves and Duvall 1995, Doody et al. 2009).
The relatively high proportion of species know to nest communally in Phyllodactylidae (Figure 2) shows that such behavior is particularly prevalent in the family. Apart from the species-rich genus Phyllodactylus, all genera have between 1 and 3 species known to lay eggs communally (Figure 2, Appendix II). The phylogenetic distribution of communal nesting in phyllodactylid genera strongly suggests that this is an ancient behavior, ancestral in the family. This finding is not particularly surprising, given that communal nesting behavior is known for members of most currently recognized Gekkota families (Doody et al. 2009). Communal nesting has not been recorded in Garthia, Asaccus or Haemodracon species, which could suggest that such behavior was lost at least twice during the evolution of the family (Figure 2). However, there is not much ecological information on the few species in these genera (Marquet et al. 1990, Razzetti et al. 2011), and future detailed studies may unearth this behavior in these genera.

Communal nesting is a recurrent feature of gecko evolution (Graves and Duvall 1995, Doody et al. 2009) and, notably, species of the family Phyllodactylidae display some of the highest levels of investment per progeny of all lizard families (Mesquita et al. 2016b). Therefore, the possible fitness gain by communal nesting might be related to the high reproductive investment in relation to the low female longevity found in Phyllopezus species (Mesquita et al. 2016b). The same relationship might explain why this behavior is present in so many phyllodactylid species (Figure 2). Although, at this stage, this should be interpreted only as a rudimentary association, studying the correlation between communal nesting evolution and reproductive investment should become a fertile field as more information on lizard nesting becomes available in the literature.

\section{Acknowledgments}

Animals were collected under Instituto Chico Mendes de Conservação da Biodiversidade 
(ICMBio) collection permit \#38749-3 to FMCBD. FMCBD acknowledges a scholarship from Coordenação de Aperfeiçoamento de Pessoal de Nível Superior (CAPES). We are grateful to Guarino R. Colli for providing access to CHUNB facilities, to Marina C. Scalon for reviewing earlier drafts of the manuscript, and to Carlos J. S. Morais for help inspecting CHUNB specimens.

\section{References}

Alfonso, Y. U., P. Charruau, G. Fajardo, and A. R. Estrada. 2012. Interspecific communal oviposition and reproduction of three lizard species in Southeastern Cuba. Herpetology Notes 5: 73-77.

Ávila, R. W. and L. R. Cunha-Avellar. 2005. Phyllopezus pollicaris reproduction. Herpetological Review 36: $453-454$.

Bezerra, A. H., D. C. Passos, P. C. M. D. Mesquita, and D. M. Borges-Nojosa. 2011. Hemidactylus agrius (Country leaf-toed gecko) reproduction. Herpetological Review 42: 274-275.

Blouin-Demers, G., P. J. Weatherhead, and J. R. Row. 2004. Phenotypic consequences of nest-site selection in black rat snakes (Elaphe obsoleta). Canadian Journal of Zoology 82: 449-456.

Bons, J. 1959. Les lacertiliens du sud-ouest Marocain. Travaux Institut Scientifique Chérifien 18: 1-130.

Cassimiro, J. and M. T. Rodrigues. 2010. Gymnodactylus darwinii (Darwin's Atlantic Rainforest Naked-toed Gecko; lagartixa-de-dedos-nus da Mata Atlântica). Communal oviposition. Herpetological Review 41: 355.

Colli, G. R. 1991. Reproductive ecology of Ameiva ameiva (Sauria, Teiidae) in the Cerrado of central Brazil. Copeia 1991: 1002-1012.

Colli, G. R., R. P. Bastos, and A. F. B. Araujo. 2002. The character and dynamics of the Cerrado herpetofauna. Pp. 223-241 in P. S. Oliveira and R. J. Marquis (ed.), The Cerrados of Brazil: Ecology and Natural History of a Neotropical Savanna. New York. Columbia University Press.

Colli, G. R., D. O. Mesquita, P. V. V. Rodrigues, and K. Kitayama. 2003. Ecology of the gecko Gymnodactylus geckoides amarali in a Neotropical savanna. Journal of Herpetology 37: 694-706.
Diaz, L. M. and S. B. Hedges. 2008. A new gecko of the genus Tarentola (Squamata: Gekkonidae) from Eastern Cuba. Zootaxa 1743: 43-52.

Disi, A. M., D. Modry, P. Necas, and L. Rifai. 2001. Amphibians and Reptiles of the Hashemite Kingdom of Jordan: an Atlas and Field Guide. Frankfurt. Chimaira. $408 \mathrm{pp}$.

Dixon, J. R. and R. B. Huey. 1970. Systematics of the lizards of the gekkonid genus Phyllodactylus of mainland South America. Contributions in Science, Los Angeles County Museum of Natural History 192: 1-77.

Doody, J. S., S. Freedberg, and J. S. Keogh. 2009. Communal egg-laying in reptiles and amphibians: evolutionary patterns and hypotheses. Quarterly Review of Biology 84: 229-252.

Eiten, G. 1972. The Cerrado vegetation of Brazil. Botanical Review 38: 201-341.

Furley, P. A. 1999. The nature and diversity of neotropical savanna vegetation with particular reference to the Brazilian cerrados. Global Ecology and Biogeography 8: 223-241.

Gamble, T., G. R. Colli, M. T. Rodrigues, F. P. Werneck, and A. M. Simons. 2012. Phylogeny and cryptic diversity in geckos (Phyllopezus; Phyllodactylidae; Gekkota) from South America's open biomes. Molecular Phylogenetics and Evolution 62: 943-53.

García-Márquez, M., L. F. López-Jurado, and J. A. Mateo. 1996. Puestas comunales en el geco Ptyodactylus oudrii. Boletín de la Asociación Herpetológica Española 7: 28-30.

Godoy, M. and D. Pincheira-Donoso. 2009. Multi-maternal nesting behaviour and a potential adaptive signal for its evolution in the Argentinean geckonid lizard Homonota borelli. Journal of Biological Research-Thessaloniki 12: $221-224$.

Gomides, S. C. and P. C. D. A. Garcia. 2014. Phyllopezus pollicaris (Brazilian Gecko, Lagartixa). Hatchling size / behavior. Herpetological Review 45: 330-331.

González de la Vega, J. P. 1988. Anfibios y Reptiles de la Provincia de Huelva. Huleva. Imprenta Jiménez, S.L. 240 pp.

Graves, B. M. and D. Duvall. 1995. Aggregation of squamate reptiles associated with gestation, oviposition, and parturition. Herpetological Monographs 9: 102-119.

Gudynas, E. 1986. Notes on the behavior of Homonota uruguayensis with special reference to elevated postures (Lacertilia: Gekkonidae). Contribuciones en Biología del Centro Educativo Don Orione 14: 1-10. 
Kushlan, J. A. 1981. Egg cache of a Galapagos gecko. Journal of Herpetology 15: 121-122.

Lima, D. C., D. C. Passos, and D. M. Borges-Nojosa. 2011. Communal nests of Phyllopezus periosus, an endemic gecko of the Caatinga of northeastern Brazil. Salamandra 47: 227-228.

López-Victoria, M., M. Jurczyk, and V. Wolters. 2013. Notes on the ecology of the Colombian leaftoed gecko (Phyllodactylus transversalis), endemic to Malpelo island. Boletín de Investigaciones Marinas y Costeras, INVEMAR 42: 319-327.

Marquet, P. A., F. Bozinović, R. G. Medel, Y. L. Werner, and F. M. Jaksić. 1990. Ecology of Garthia gaudichaudi, a gecko endemic to the semiarid region of Chile. Journal of Herpetology 24: 431-434.

Meiri, S., J. H. Brown, and R. M. Sibly. 2012. The ecology of lizard reproductive output. Global Ecology and Biogeography 21: 592-602.

Meiri, S., A. Feldman, and L. Kratochvíl. 2015. Squamate hatchling size and the evolutionary causes of negative offspring size allometry. Journal of Evolutionary Biology 28: 438-446.

Mesquita, D. O., G. R. Colli, G. C. Costa, T. B. Costa, D. B. Shepard, L. J. Vitt, and E. R. Pianka. 2015. Life history data of lizards of the world. Ecology 96: 594-594.

Mesquita, D. O., G. C. Costa, G. R. Colli, T. B. Costa, D. B. Shepard, L. J. Vitt, and E. R. Pianka. 2016a. Life-history patterns of lizards of the world. American Naturalist 187: 689-705.

Mesquita, D. O., R. G. Faria, G. R. Colli, L. J. Vitt, and E. R. Pianka. 2016b. Lizard life-history strategies. Austral Ecology 41: 1-5.

Myers, N., R. A. Mittermeier, C. G. Mittermeier, G. A. B. da Fonseca, and J. Kent. 2000. Biodiversity hotspots for conservation priorities. Nature 403: 853-858.

Noble, G. K. and E. R. Mason. 1933. Experiments on the brooding habits of the lizards Eumeces and Ophisaurus. American Museum Novitates 619: 1-29.

Nogueira, C., S. Ribeiro, G. C. Costa, and G. R. Colli. 2011. Vicariance and endemism in a Neotropical savanna hotspot: distribution patterns of Cerrado squamate reptiles. Journal of Biogeography 38: 1907-1922.

Novo, J. 1985. Nido comunal de Anolis angusticeps (Sauria: Iguanidae) en Cayo Francés, Cuba. Miscelánea Zoológica 28: 2-3.

Oda, W. Y. 2004. Communal egg laying by Gonatodes humeralis (Sauria, Gekkonidae) in Manaus primary and secondary forest areas. Acta Amazonica 34: 331-332.
Oliveira, B. H. S., R. N. M. Queiroz, and D. O. Mesquita. 2015. Communal nests and hatchling size of Coleodactylus meridionalis (Squamata: Sphaerodactylidae) in a Caatinga area, northeastern Brazil. Herpetology Notes 8: $125-128$.

Paradis, E., J. Claude, and K. Strimmer. 2004. APE: Analyses of Phylogenetics and Evolution in $\mathrm{R}$ language. Bioinformatics 20: 289-290.

Petzold, H. G. 1982. Aufgaben und probleme der tiergaertnerei bei der erforschung der lebensaeusserungen der niederen amnioten (Reptilien). Milu, Berlin 5: 485786.

Pike, D. A., R. M. Andrews, and W.-G. Du. 2011. Eggshell morphology and gekkotan life-history evolution. Evolutionary Ecology 26: 847-861.

R Core Team. 2016. R: A language and environment for statistical computing. https://www.R-project.org.

Radder, R. S. and R. Shine. 2007. Why do female lizards lay their eggs in communal nests? Journal of Animal Ecology 76: 881-887.

Rand, A. S. 1967. Communal egg laying in Anoline lizards. Herpetologica 23: 227-230.

Razzetti, E., R. Sindaco, C. Grieco, F. Pella, U. Ziliani, F. Pupin, E. Riservato, D. Pellitteri-Rosa, L. Butikofer, and A. S. Suleiman. 2011. Annotated checklist and distribution of the Socotran Archipelago Herpetofauna (Reptilia). Zootaxa 2826: 1-44.

Recoder, R., M. Teixeira Júnior, A. Camacho, and M. T. Rodrigues. 2012. Natural history of the tropical gecko Phyllopezus pollicaris (Squamata, Phyllodactylidae) from a sandstone outcrop in Central Brazil. Herpetology Notes 5: 49-58.

Righi, A., C. Galdino, and L. Nascimento. 2004. Phyllopezus pollicaris (Rock Gecko) clutch size and oviposition sites. Herpetological Review 35: 395-396.

Righi, A. F., L. B. Nascimento, and C. A. B. Galdino. 2012. Seasonal reproduction in the rock gecko Phyllopezus pollicaris from a rock field habitat in southeastern Brazil. Journal of Herpetology 46: 632-636.

Roobol, M., J. Pint, M. Al-Shanti, A. Al-Juaid, S. AlAmoudi, S. Pint, A. Al-Eisa, F. Allam, G. Al-Sulaimani, and A. Banakhar. 2002. Preliminary Survey for LavaTube Caves on Harrat Kishb. Jeddah. Kingdom of Saudi Arabia. 35 pp.

Schwartz, A. 1968. Geographic variation in the New World geckkonid lizard Tarentola americana Gray. Proceedings of the Biological Society of Washington 81: $123-142$. 
Schwartz, A. and R. W. Henderson. 1991. Amphibians and Reptiles of the West Indies: Descriptions, Distributions, and Natural history. Gainesville. University Press of Florida. 727 pp.

Sinervo, B. 1994. Experimental tests of reproductive allocation paradigms. Pp. 73-90 in L. J. Vitt and E. R. Pianka (ed.), Lizard Ecology: Historical and Experimental Perspectives. Princeton. Princeton University Press.

Souza, M. C., A. C. Franco, M. Haridasan, D. R. Rossatto, J. F. D. Araújo, L. P. C. Morellato, and G. Habermann. 2015. The length of the dry season may be associated with leaf scleromorphism in Cerrado plants. Anais da Academia Brasileira de Ciências 87: 1691-1699.

Tonini, J. F. R., K. H. Beard, R. B. Ferreira, W. Jetz, and R. A. Pyron. 2016. Fully-sampled phylogenies of squamates reveal evolutionary patterns in threat status. Biological Conservation 204: 23-31.

Torres-Carvajal, O., A. Carvajal-Campos, C. W. Barnes, G. Nicholls, and M. J. Pozo-Andrade. 2013. A new Andean species of Leaf-toed gecko (Phyllodactylidae: Phyllodactylus) from Ecuador. Journal of Herpetology 47: $384-390$

Uetz, P. (ed.). 2016. The Reptile Database. Eletronic Database accessible at http://www.reptile-database.org. Captured on 20 November 2016.

Vitt, L. J. 1986. Reproductive tactics of sympatric gekkonid lizards with a comment on the evolutionary and ecological consequences of invariant clutch size. Copeia 1986: 773-786.

Vitt, L. J., P. A. Zani, and A. A. M. Barros. 1997. Ecological variation among populations of the gekkonid lizard Gonatodes humeralis in the Amazon Basin. Copeia 1997: 32-43.
Werneck, F. P. and G. R. Colli. 2006. The lizard assemblage from seasonally dry tropical forest enclaves in the Cerrado biome, Brazil, and its association with the Pleistocenic Arc. Journal of Biogeography 33: 19831992.

Werneck, F. P., G. R. Colli, and L. J. Vitt. 2009. Determinants of assemblage structure in Neotropical dry forest lizards. Austral Ecology 34: 97-115.

Werneck, F. P., T. Gamble, G. R. Colli, M. T. Rodrigues, and J. W. Sites Jr. 2012. Deep diversification and longterm persistence in the South American 'Dry Diagonal': Integrating continent-wide phylogeography and distribution modeling of geckos. Evolution 66: 3014-3034.

Werner, D. 1972. Beobachtungen an Ptyodactylus hasselquistii guttatus (Geckonidae). Verhandlungen der Naturforschenden Gesellshaft in Basel 82: 54-87.

Werner, Y. L. 1965. Uber die israelischen geckos der gattung Ptyodactylus und ihre biologie. Salamandra 1: 15-25.

Werner, Y. L. 1986. Ecology of eggs and laying sites of Ptyodactylus geckos. Pp. 441-444 in Z. Rocek (ed.), Studies in Herpetology: Proceedings of the European Herpetological Meeting. Prague. Charles University.

Wiederhecker, H. C., A. C. Pinto, and G. R. Colli. 2002. Reproductive ecology of Tropidurus torquatus (Squamata: Tropiduridae) in the highly seasonal Cerrado biome of central Brazil. Journal of Herpetology 36: 82-91. 


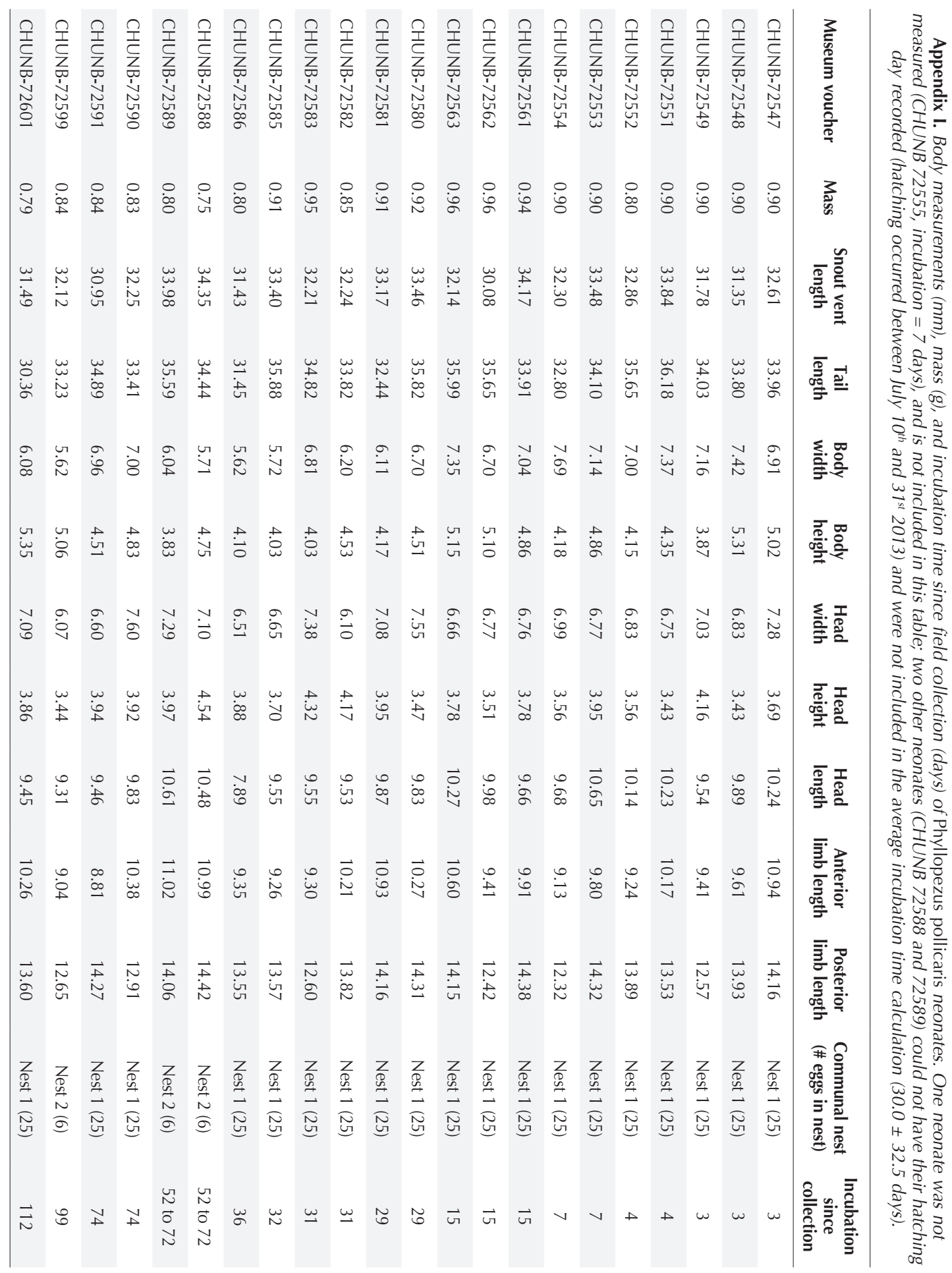


Appendix II. Phylogenetic tree depicting all currently recognized species in the family Phyllodactylidae, extracted from Tonini et al. (2016). Species known to lay eggs communally are in black, and species for which no evidence of communal nesting is available are in gray.

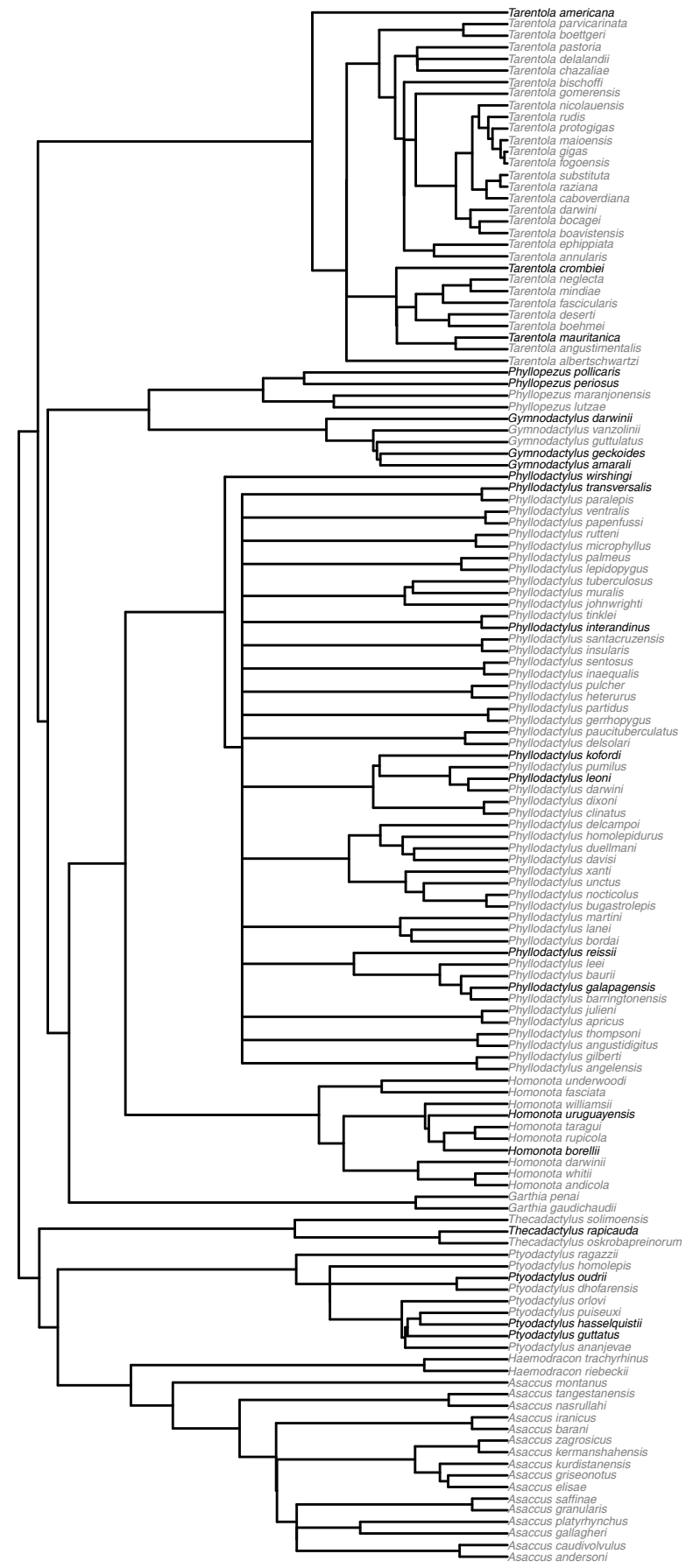

